\title{
Knowledge of Mothers Regarding Measles Control in Primary Health Care Centers in Al- Samawa City
}

\author{
Salwan Abdullah Naji , Khadija S. AL-Mizury, Shatha K. Atrah \\ Community Health Department/College of Health and Medical Technology Baghdad/Middle Technical \\ University/Iraq
}

\begin{abstract}
Background:Measles is a very communicable viral illness that can be prevented by immunization. knowledge is key tools to control of disease.

Objectives:The aims of study were identify mothers knowledge regarding measles control and immunization.

Methods:A cross sectional study (descriptive study) was conducted in Al-Samawa city/Iraq during the period between 2/3/ 2019 to1/7/ 2019. Data collected from (450) mothers who have at least one child less than(5)years of age,though using a special questionnaire format.

Results: The study finding out about (72.9\%) of mothers participant were acceptable knowledge of measles control and $(24.4 \%)$ were poor knowledge while the(2.4\%) have agood knowledge.

Conclusion:The study concluded most of mothers had been acceptable levels for knowledge. However, educational program is still needed to increase the parents' knowledge especially among illiterate and less educated parents.
\end{abstract}

Keywords:Knowledge, Immunization, Vaccination.

\section{Introduction}

Measles is a very communicable viral illness that can be prevented by immunization ${ }^{(1)}$. Most cases of measles occur during the dry season and in areas with temperate climates, the peak occurs during late winter and early spring ${ }^{(2)}$. Measles is decreased because of immunization but many areas of the world continue to experience outbreaks ${ }^{(1)}$.It is spread by coughing and sneezing,close personal contact ${ }^{(3)}$.Measles characterized by fever,cough,coryza, and conjunctivitis, followed by a maculopapular rash, during the prodromal period, aKoplik spots may be present ${ }^{(1)}$. Vaccination is one of the most cost-effective interventions to prevent major illnesses that contribute to child mortality ${ }^{(1)}$. Measles vaccines are safe, effective and providing a crucial tool for global measles elimination ${ }^{(2)}$.To prevent recurrent outbreaks of measles, 95 percent of the population must be immune $\left.{ }^{(3)}\right)$.Several attenuated measles vaccines are available worldwide, either as single-virus vaccines or in combination with other vaccine viruses (commonly rubella and mumps) $)^{(2)}$.Elimination of an infectious disease is mean the total absence of cases in a population. This situation can occur only if the entire population is immune as a result of either natural disease or vaccination ${ }^{(3)}$. Determine knowledge of mothers regarding measles which helpful to control, The aims of study were to determine mothers knowledge regarding measles control and identify mothers information source regarding measles control.

\section{Material \& Subject}

\section{Study design}

A cross sectional study was carried out in AlSamawa city for the period between 2/3/2019 to1/7/2019. The study included(450)mothers at reproductive age, whose had at last one child or more under five years of ages, attended to primary health care center. This study included an interview with the mothers and using aspecial questionnaire format. The questionnaire contained 3 
different parts. The first part included questions about the demographic characteristic and other 2 parts included questions about the knowledge and information source of mother toward measles control and vaccination .

\section{Statistical Analysis}

Analysis of data was carried out using the Statistical Packages for Social Sciences(SPSS-25) Data were presented in simple measures of frequency, percentage, mean, standard deviation, and range (minimummaximum values).

The significance of difference for different percentages(qualitative data)were tested using Pearson Chi-square test $\left(\chi^{2}\right.$-test $)$ with application of Yate's correction or Fisher Exact test whenever applicable. Statistical significance was considered whenever the $\mathrm{P}$ value was equal or less than 0.05 .

\section{Results}

Table1:Distribution mothers participant according to the Socio-demographic characteristic.

\begin{tabular}{|c|c|c|c|}
\hline \multicolumn{2}{|c|}{ I=Sociodemographic characteristic } & \multirow{2}{*}{$\begin{array}{l}\text { No } \\
209\end{array}$} & \multirow{2}{*}{$\frac{\%}{46.4}$} \\
\hline & Rural & & \\
\hline 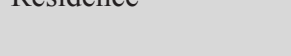 & Urban & 241 & 53.6 \\
\hline \multirow{7}{*}{ Age of mother(years) } & $<20 \mathrm{y}$ & 13 & 2.9 \\
\hline & $20---24$ & 69 & 15.3 \\
\hline & $25---29$ & 99 & 22.0 \\
\hline & $30---34$ & 99 & 22.0 \\
\hline & $35---39$ & 121 & 26.9 \\
\hline & $=>40 \mathrm{y}$ & 49 & 10.9 \\
\hline & Mean \pm SD (Range) & \multicolumn{2}{|c|}{$31.4 \pm 6.5(17-44)$} \\
\hline \multirow{3}{*}{ Marital status } & Married & 395 & 87.8 \\
\hline & Separated & 33 & 7.3 \\
\hline & Widow & 22 & 4.9 \\
\hline \multirow{7}{*}{ Mother's educational } & Illiterate & 34 & 7.6 \\
\hline & Read \& Write & 86 & 19.1 \\
\hline & Primary & 106 & 23.6 \\
\hline & Intermediate & 39 & 8.7 \\
\hline & Secondary & 67 & 14.9 \\
\hline & Institute & 70 & 15.6 \\
\hline & College \& higher & 48 & 10.7 \\
\hline
\end{tabular}


Cont... Table1: Distribution mothers participant according to the Socio-demographic characteristic.

\begin{tabular}{|c|c|c|c|}
\hline \multirow{5}{*}{ Mother's occupation } & Governmental employee & 110 & 24.4 \\
\hline & Self-employee & 3 & .7 \\
\hline & Retired & - & - \\
\hline & Student & 8 & 1.8 \\
\hline & Housewife & 329 & 73.1 \\
\hline \multirow{5}{*}{ Number of child } & 1 & 21 & 4.7 \\
\hline & 2 & 55 & 12.2 \\
\hline & 3 & 142 & 31.6 \\
\hline & 4 & 136 & 30.2 \\
\hline & $\Rightarrow>5$ & 96 & 21.4 \\
\hline \multirow{4}{*}{ Number of rooms } & 1 & 7 & 1.6 \\
\hline & 2 & 355 & 78.9 \\
\hline & 3 & 82 & 18.2 \\
\hline & $\Rightarrow>4$ & 6 & 1.4 \\
\hline \multirow{9}{*}{ Family members } & 1 & 2 & .4 \\
\hline & 3 & 10 & 2.2 \\
\hline & 4 & 42 & 9.3 \\
\hline & 5 & 124 & 27.6 \\
\hline & 6 & 107 & 23.8 \\
\hline & 7 & 53 & 11.8 \\
\hline & 8 & 48 & 10.7 \\
\hline & 9 & 24 & 5.3 \\
\hline & $\Rightarrow>10$ & 40 & 8.7 \\
\hline \multirow{5}{*}{ Crowding Index } & $=<1.0 \mathrm{CI}$ & 37 & 8.2 \\
\hline & 2.0--- & 177 & 39.3 \\
\hline & 3.0--- & 145 & 32.2 \\
\hline & 4.0--- & 66 & 14.7 \\
\hline & $\Rightarrow 5.0 \mathrm{CI}$ & 25 & 5.6 \\
\hline \multirow{3}{*}{ Type of house } & Owned & 216 & 48.0 \\
\hline & Rented & 130 & 28.9 \\
\hline & Shared & 104 & 23.1 \\
\hline
\end{tabular}


Table(1)shows that(53.6\%)from mothers participant were living in urban area with mother's age group the highest percentage were from(35-39)years were accounted(26.9\%)and(87.8\%)were married. Regarding to the education level of mothers participant were primary school graduate accounted(23.6\%).About the mother's occupation majority of mothers participant were housewife(73.1\%), while the number of child, major part of mother's participant have three children were accounted(31.6\%).

Lastly, crowding index refer to $2^{\text {nd }}$ class(2up to4) personal sharing in the room , they accounted(86.2\%).

Table(2):Distribution the mothers participant according the knowledge item.

\begin{tabular}{|c|c|c|c|c|c|c|}
\hline \multirow{2}{*}{ II=Mother's Knowledge } & \multicolumn{2}{|c|}{ Yes } & \multicolumn{2}{|c|}{ No } & \multicolumn{2}{|c|}{ DNK } \\
\hline & No & $\%$ & No & $\%$ & No & $\%$ \\
\hline Know about measles & 443 & 98.4 & - & - & 7 & 1.6 \\
\hline \multirow{3}{*}{ Measles causes by; } & 188 & 41.8 & & & & \\
\hline & 154 & 34.2 & & & & \\
\hline & 85 & 18.9 & & & & \\
\hline DNK & 23 & 5.1 & & & & \\
\hline $\begin{array}{r}\text { Mode of transmission of measles by; } \\
\text {-Droplet and airborne }\end{array}$ & 215 & 47.8 & 192 & 42.7 & 43 & 9.6 \\
\hline -Feco-oral & 292 & 64.9 & 123 & 27.3 & 35 & 7.8 \\
\hline -Direct contact & 176 & 39.1 & 247 & 54.9 & 27 & 6.0 \\
\hline -Clothes and fomites & 114 & 25.3 & 310 & 68.9 & 26 & 5.8 \\
\hline $\begin{array}{r}\text { Singe and symptom of measles; } \\
\text {-High fever }\end{array}$ & 326 & 72.4 & 87 & 19.3 & 37 & 8.2 \\
\hline -Cough & 87 & 19.3 & 303 & 67.3 & 60 & 13.3 \\
\hline -Runny nose(coryza) & 13 & 2.9 & 394 & 87.6 & 43 & 9.6 \\
\hline -Conjunctivitis & 5 & 1.1 & 395 & 87.8 & 50 & 11.1 \\
\hline -Rash & 356 & 79.1 & 65 & 14.4 & 29 & 6.4 \\
\hline There is avaccine available to prevent measles & 438 & 97.3 & 2 & .4 & 10 & 2.2 \\
\hline $\begin{array}{l}\text { The name of vaccine is; } \\
\text {-Tetanus Toxoid Vaccine }\end{array}$ & 41 & 9.1 & 388 & 86.2 & 21 & 4.7 \\
\hline -Measles Vaccine & 421 & 93.6 & 15 & 3.3 & 14 & 3.1 \\
\hline -DPT Vaccine & 194 & 43.1 & 224 & 49.8 & 32 & 7.1 \\
\hline -MMR Vaccine & 307 & 68.2 & 104 & 23.1 & 39 & 8.7 \\
\hline -OPV Vaccine & 3 & 7 & 426 & 94.7 & 21 & 4.7 \\
\hline -BCG Vaccine & 20 & 4.4 & 410 & 91.1 & 20 & 4.4 \\
\hline -Tetra Vaccine & 135 & 30.0 & 297 & 66.0 & 18 & 4.0 \\
\hline -Penta Vaccine & 100 & 22.2 & 324 & 72.0 & 26 & 5.8 \\
\hline
\end{tabular}


Cont... Table(2):Distribution the mothers participant according the knowledge item.

\begin{tabular}{|c|c|c|c|c|c|c|}
\hline $\begin{array}{r}\text { The age measles vaccine should be given to baby;-At } \\
\text { birth }\end{array}$ & 15 & 3.3 & 410 & 91.1 & 25 & 5.6 \\
\hline-2 months & 19 & 4.2 & 414 & 92.0 & 17 & 3.8 \\
\hline-4 months & 56 & 12.4 & 365 & 81.1 & 29 & 6.4 \\
\hline-6 months & 158 & 35.1 & 235 & 52.2 & 57 & 12.7 \\
\hline-9 months & 277 & 61.6 & 154 & 34.2 & 19 & 4.2 \\
\hline-15 months & 110 & 24.4 & 313 & 69.6 & 27 & 6.0 \\
\hline-18 months & 51 & 11.3 & 362 & 80.4 & 37 & 8.2 \\
\hline -Preschool(4-6 years) & 118 & 26.2 & 320 & 71.1 & 12 & 2.7 \\
\hline $\begin{array}{r}\text { The age MMRvaccine should be given to baby;-At } \\
\text { birth }\end{array}$ & 51 & 11.3 & 362 & 80.4 & 37 & 8.2 \\
\hline-2 months & 48 & 10.7 & 363 & 80.7 & 39 & 8.7 \\
\hline-4 months & 36 & 8.0 & 386 & 85.8 & 28 & 6.2 \\
\hline-6 months & 62 & 13.8 & 359 & 79.8 & 29 & 6.4 \\
\hline-9 months & 94 & 20.8 & 315 & 70.0 & 41 & 9.1 \\
\hline-15 months & 274 & 60.9 & 162 & 36.0 & 14 & 3.1 \\
\hline-18 months & 96 & 21.3 & 318 & 70.7 & 36 & 8.0 \\
\hline -Preschool(4-6 years) & 197 & 43.8 & 227 & 50.4 & 26 & 5.8 \\
\hline Frequent campaigns are useful for child & 419 & 93.1 & 31 & 6.9 & - & - \\
\hline $\begin{array}{r}\text { Frequent campaigns replace the routine vaccination } \\
\text { in PHCC }\end{array}$ & 200 & 44.4 & 217 & 48.2 & 33 & 7.3 \\
\hline Know measles control and elimination is important & 431 & 95.8 & - & - & 19 & 4.2 \\
\hline $\begin{array}{r}\text { Have the desire to know about measles and MMR } \\
\text { vaccination }\end{array}$ & 308 & 68.4 & 113 & 25.1 & 29 & 6.4 \\
\hline $\begin{array}{r}\text { Heard about any side effect measles and MMR } \\
\text { vaccination }\end{array}$ & 394 & 87.6 & 56 & 12.4 & - & - \\
\hline $\begin{array}{r}\text { Immunize the child; The side effect observed was;- } \\
\text { Fever }\end{array}$ & 236 & 52.4 & 214 & 47.6 & - & - \\
\hline -Pain and swelling in site of injection & 230 & 51.1 & 220 & 48.9 & - & - \\
\hline -Rash & 79 & 17.6 & 371 & 82.4 & - & - \\
\hline -Headache & 44 & 9.8 & 406 & 90.2 & - & - \\
\hline
\end{tabular}

Table (2) shows the $(42 \%)$ of mothers participant answered correctly for measles causes by virus, while (47.8\%),(39.1\%),(25.3\%) know correctly the measles transmission by droplet and airborne, direct contact and clothes and fomites respectively, high percentage $(72.4 \%, 79.1 \%)$ from mothers participant know the measles accompanied by fever and rash. The majority (97.3\%)from their know correctly the vaccine available. About(93.6\%),(68.2\%) of mothers answered correctly about vaccine name to prevent measles while that $(61.6 \%),(60.9 \%),(43.8 \%)$ respectively from mothers know correctly the child age should be given the vaccine. High percentage $(52.4 \%, 51.1 \%)$ of mothers observed side effect as fever, pain and swelling in site of injection when immunize their child. 
Overall score for knowledge in figure (1)in which majority $(72.9 \%)$ of mothers participant were acceptable knowledge of measles control and (24.4\%) were poor knowledge while the $(2.4 \%)$ have agood knowledge.

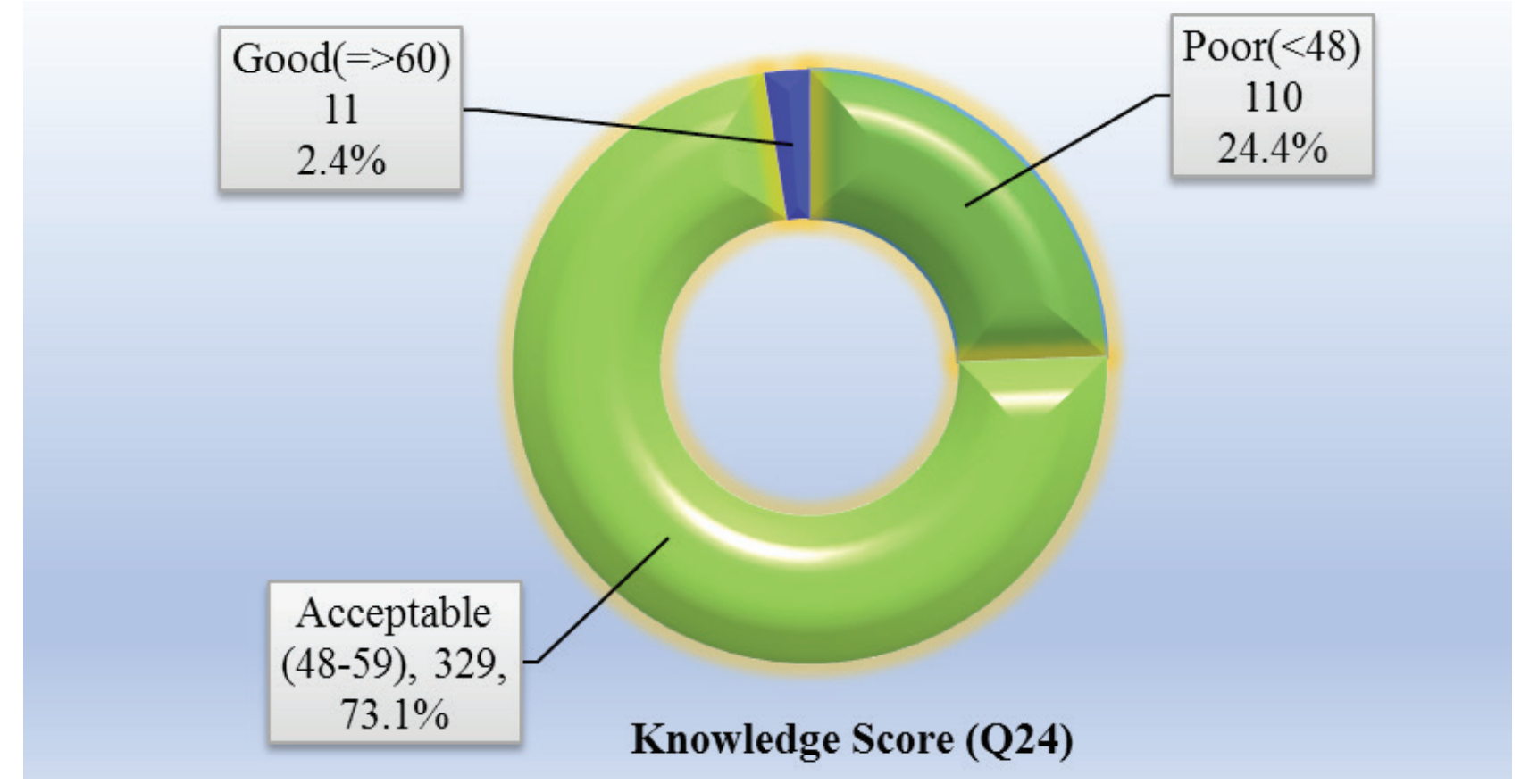

Figure(1)score for knowledge

Table(3):Distribution the mothers participant according to information source.

\begin{tabular}{|l|l|l|}
\hline information source & No & $\%$ \\
\hline -Health workers & 416 & 92.4 \\
\hline -TV\&radio & 213 & 47.3 \\
\hline -Social media(internet/Facebook) & 182 & 40.4 \\
\hline -Neighbors & 83 & 18.4 \\
\hline -Relatives \& friends & 51 & 11.3 \\
\hline
\end{tabular}


Table(3)shows that health workers registered high percentage among studied mothers, were accounted(92.4\%).

Table(4): Association between socio-demographic characteristic of mothers participant and Knowledge score.

\begin{tabular}{|c|c|c|c|c|c|c|}
\hline \multirow{3}{*}{\multicolumn{2}{|c|}{ I=Sociodemographic characteristic }} & \multicolumn{5}{|c|}{ Knowledge Score(Q24) } \\
\hline & & \multicolumn{2}{|c|}{$\operatorname{Poor}(<48)$} & \multicolumn{2}{|c|}{ Acceptable/Good( $=>48)$} & \multirow{2}{*}{ P value } \\
\hline & & No & $\%$ & No & $\%$ & \\
\hline \multirow{2}{*}{ Residence } & Rural & 57 & 51.8 & 152 & 44.7 & 0.194 \\
\hline & Urban & 53 & 48.2 & 188 & 55.3 & \\
\hline \multirow{6}{*}{$\begin{array}{l}\text { Age of mother } \\
\text { (years) }\end{array}$} & $<20 y$ & 4 & 3.6 & 9 & 2.6 & 0.753 \\
\hline & $20---24$ & 15 & 13.6 & 54 & 15.9 & \\
\hline & $25---29$ & 20 & 18.2 & 79 & 23.2 & \\
\hline & $30---34$ & 25 & 22.7 & 74 & 21.8 & \\
\hline & $35---39$ & 31 & 28.2 & 90 & 26.5 & \\
\hline & $=>40 y$ & 15 & 13.6 & 34 & 10.0 & \\
\hline \multirow{3}{*}{ Marital status } & Married & 98 & 89.1 & 297 & 87.4 & 0.882 \\
\hline & Separated & 7 & 6.4 & 26 & 7.6 & \\
\hline & Widow & 5 & 4.5 & 17 & 5.0 & \\
\hline \multirow{7}{*}{$\begin{array}{l}\text { Mother's } \\
\text { educational }\end{array}$} & Illiterate & 11 & 10.0 & 21 & 6.2 & $0.0001 *$ \\
\hline & Read \& Write & 43 & 39.1 & 43 & 12.6 & \\
\hline & Primary & 37 & 33.6 & 69 & 20.3 & \\
\hline & Intermediate & 16 & 14.5 & 25 & 7.1 & \\
\hline & Secondary & 3 & 2.7 & 64 & 18.8 & \\
\hline & Institute & - & - & 70 & 20.6 & \\
\hline & College \& higher & - & - & 48 & 14.1 & \\
\hline \multirow{4}{*}{$\begin{array}{l}\text { Mother's } \\
\text { occupation }\end{array}$} & Governmental employee & - & - & 110 & 32.4 & $0.0001 *$ \\
\hline & Self-employee & - & - & 3 & 0.9 & \\
\hline & Student & - & - & 8 & 2.4 & \\
\hline & Housewife & 110 & 100.0 & 219 & 64.4 & \\
\hline
\end{tabular}


Cont... Table(4):Association between socio-demographic characteristic of mothers participant and Knowledge score.

\begin{tabular}{|c|c|c|c|c|c|c|}
\hline \multirow{5}{*}{ Number of child } & 1 & 4 & 3.6 & 17 & 5.0 & 0.478 \\
\hline & 2 & 9 & 8.2 & 46 & 13.5 & \\
\hline & 3 & 36 & 32.7 & 106 & 31.2 & \\
\hline & 4 & 33 & 30.0 & 103 & 30.3 & \\
\hline & $=>5$ & 28 & 25.5 & 68 & 20.0 & \\
\hline \multirow{5}{*}{ Crowding Index } & $=<1.0 \mathrm{CI}$ & 1 & 0.9 & 36 & 10.6 & $0.0001 *$ \\
\hline & 2.0--- & 36 & 32.7 & 141 & 41.5 & \\
\hline & 3.0--- & 36 & 32.7 & 109 & 32.1 & \\
\hline & 4.0--- & 23 & 20.9 & 43 & 12.6 & \\
\hline & $=>5.0 \mathrm{CI}$ & 14 & 12.7 & 11 & 3.2 & \\
\hline \multirow{3}{*}{ Type of house } & Owned & 46 & 41.8 & 170 & 50.0 & $0.024 *$ \\
\hline & Rented & 43 & 39.1 & 87 & 25.6 & \\
\hline & Shared & 21 & 19.1 & 83 & 24.4 & \\
\hline
\end{tabular}

Table(4)show significant association at $\mathrm{P}<0.05$ among total Knowledge and difference levels of demographic variable (level of educational, mother's occupation, crowding Index and type of house).

Table(5):Association between information source and knowledge score.

\begin{tabular}{|c|c|c|c|c|c|c|}
\hline & & \multicolumn{5}{|c|}{ Knowledge Score (Q24) } \\
\hline \multicolumn{2}{|c|}{ Source of information } & \multicolumn{2}{|c|}{ Poor $(<48)$} & \multicolumn{2}{|c|}{ Acceptable/Good (=>48) } & \multirow{3}{*}{$\begin{array}{l}\text { P value } \\
0.001 *\end{array}$} \\
\hline & & No & $\%$ & No & $\%$ & \\
\hline \multirow{2}{*}{-TV\&radio } & Yes & 35 & 31.8 & 178 & 52.4 & \\
\hline & No & 75 & 68.2 & 162 & 47.6 & \\
\hline \multirow{2}{*}{-Social media (internet/Facebook) } & Yes & 12 & 10.9 & 170 & 50.0 & $0.001 *$ \\
\hline & No & 98 & 89.1 & 170 & 50.0 & \\
\hline \multirow{2}{*}{-Relatives \& friends } & Yes & 4 & 3.6 & 47 & 13.8 & 0.775 \\
\hline & No & 106 & 96.4 & 293 & 86.2 & \\
\hline \multirow{2}{*}{-Neighbors } & Yes & 8 & 7.3 & 75 & 22.1 & $0.001 *$ \\
\hline & No & 102 & 92.7 & 265 & 77.9 & \\
\hline \multirow{2}{*}{-Health workers } & Yes & 101 & 91.8 & 315 & 92.6 & $0.0001 *$ \\
\hline & No & 9 & 8.2 & 25 & 7.4 & \\
\hline
\end{tabular}


Table(5)shows predominant information source of knowledge was health worker about $(92.6 \%)$ and statistically high significant association at $\mathrm{P}<(0.01)$.

\section{Discussion}

The results of the study offer insight to the knowledge of mothers regarding measles control in Al-Samawa city, and can be utilize to conduct of population.

Table(1)show the majority percentage(53.6\%) were from urban area, this result was similar to study result done in Iraq ${ }^{(4)}$. Regarding to age group of mother participant the study result revealed that most of mother's age group were(35-39)years, with Mean \pm SD of their age(31.4 \pm 6.5$)$, our result found $(87.8 \%)$ were married, this result was agree with study result done in Iraq $^{(5)}$ and in Jordan ${ }^{(6)}$. Present study showed a high percentage was primary school level(23.6\%)this result was accordance with study result done in $\operatorname{India}^{(7)}$ and discordance with other study result done in Jordan ${ }^{(6)}$ who found $(44.5 \%)$ were university and higher level .This difference attributed to variation in socio-economical status between the communities.

Regarding to occupation aspect, in our study the majorty of mothers were house wife, they were accounted(73.1\%), this may be due to the most mothers were unable to work because low education level, family responsibility, aging and lost opportunity to find work. This result was similar to the study result done in Iraq ${ }^{(4)}$ and in $(\mathrm{KSA})^{(8)}$.

About the crowding index refer to $2^{\text {nd }}$ class(2up to 4 ) personal sharing in the room, they accounted(86.2\%). A strong relationship between crowding index of family and measles vaccination coverage rate, this may be attributed to higher education level of families with high economic status, lead to good awareness about of important the measles vaccination.

Table(2)reveal that $(98.4 \%$ )of their know about measles, this result was similar to the result study done in China ${ }^{(9)}$. Regarding to item of is measles / viral, our study show accounted(41.8\%)of mothers participant know measles is viral disease, this finding disagree with study conducted in Switzerland ${ }^{(10)}$, who reproted that mothers partcipant were $(85.8 \%)$ know measles is viral disease this difference may due to differ in level of health eduaction and culture status bettween the commuites. According to item "mode of transmission"by; droplet and airborne, direct contact and clothes and fomites the correctly answered were $(47.8 \%),(39.1 \%),(25.3 \%)$ respectively, our result agree with result study conducted in India ${ }^{(11)}$. About the "singe and symptom" high percentage( $79.1 \%, 72.4 \%$ ) from mothers participant know the measles accompanied by rash and fever, this finding were accordance to report of study in India ${ }^{(11)}$. According to item "there is a vaccine available to prevent measles"the majority of mothers participant were accounted(97.3\%)know correctly,this result similar to other study done in $\operatorname{KAS}^{(8)}$. About(93.6\%) of mothers participant answered correctly for vaccine name, this a high knowledge percentages for vaccine name may be due to the fact that the vaccines are named by the diseases they prevent. This result agree with study results done in $\operatorname{Nigeria}^{(12)}$

The study finding regarding to child age should be given the vaccine (measles, MMR) around $(61.6 \%),(60.9 \%),(43.8 \%)$ respectively from mothers participant answered correctly, this finding accordance with study done in China ${ }^{(9)}$. About subject "frequent campaigns are useful for child"(93.1\%)of mothers sample answer"Yes", our result similarity to study reported in Iraq ${ }^{(13)} \quad$ The current study showed large number(95.8\%)of mothers participant know measles control and elimination is important, this result similar to study result done in $\operatorname{Iraq}^{(4)}$. Our study found the percentage $(52.4 \%, 51.1 \%)$ of mothers participant observed side effect as fever, pain and swelling in site of injection respectively when immunize their child, this finding accordance with study result done in $\operatorname{Iraq}^{(4) .}$

Table(3)shows, each mothers participant might have one or more from different information source about measles and vaccination. Our study reported(92.4\%)of their consider the health workers as information source. Our finding accordance with study result done in Iraq ${ }^{(5)}$. Our study found that $(47.3 \%$ )of their who reported TVas information source, this result compatible with study result done in $\operatorname{Egypt}^{(16)}$.

As for items" social media(internet/ facebook),relatives \& friends and neighbors"were accounted(40.4\%),(11.3\%),(18.4\%)respectively, our finding similar with finding in $\operatorname{Iraq}^{(4)}(13)$ 
Table(4)demonstration there was no significant association between knowledge and (residence, age of mother and marital status) of mothers participant, while relationship between knowledge and mother's educational level and mother's occupation was statistically significant at $(\mathrm{P}<0.01)$, this results matched with study result done in Egypt ${ }^{(14)}$

Another finding in study was asignificant relationship at $(\mathrm{P}<0.01)$ between knowledge and crowding index and type of house, this result agree with other study result done in $\operatorname{Iraq}^{(15)}$

Table(5)shows the association between health worker as (information source) of mothers participant and knowledge was ahigher significant at $\mathrm{p}<(0.001)$. Similarly to studies reported in $\operatorname{Iraq}^{(6)}$. While about the items"TV\&radio, social media(internet/facebook) and neighbors" as information source was significant association with knowledge of mothers participant at $\mathrm{P}<(0.05)$. Our finding agree with study done in $(\mathrm{KSA})^{(9)}$.

\section{Conclusion}

Most of mothers had been acceptable level for knowledge and receive information from health worker.

Conflict of Interest : none

\section{Source of Funding : self}

Ethical Clearance : From patients and my college .

\section{Referances}

1. Center for Diseases Control and Prevent (CDC) Epidemiology and Prevention of VaccinePreventable Diseases,13th.United States of America.2015 .doi:10.1016/B978-0-12-8036785.00270-8.

2. WHO Measles vaccines:WHO position paper, April 2017-Recommendations,Vaccine. 2017. doi: 10.1016/J.VACCINE.2017.07.066.

3. WHO 'Epidemiology Measles',(November 2017).

4. Suha, A. K. 'Assessment mother's knowledge concerning child immunization in primery health care centers in Baquba city', Diyala Journal of Medicine,2015.9(2),pp.25-33.

5. Al-lela,O.Q.B.'Are parents knowledge and practice regarding immunization related to pediatrics , immunization compliance? a mixed method study', BMC Pediatrics, 2014.14(20),pp.14-20.

6. Masadeh, M.M. Alzoubi, Karem H. Al-Azzam, Sayer I. Al-Agedi, Hassan S.Abu Rashid, Baraa E. Mukattash, Tariq L.M. M.'Public awareness regarding children vaccination in Jordan , Human Vaccines and Immunotherapeutics, 2014.10(6), pp.1762-1766. doi:10.4161/hv.28608.

7. Mahalingam, S. M., Soundarya Soori, Abhijna Ram, Pradhum Achappa, Basavaprabhu Chowta, Mukta Madi, Deepak 'Knowledge, attitude and perceptions of mothers with children under five years of age about vaccination in Mangalore,India', Asian Journal of Medical Sciences, 2014.5(4),pp 52-57.doi:10.3126 /ajms .v5i4.10306.

8. Abdullah, A.A, Saleh Alshareef, Reem Ahmed Alabudib, Fatimah Abduladhim. 'Assessment of Knowledge and Attitude and Practice of Parents about Immunization in Jeddah City, ,The Egyptian Journal of Hospital Medicine, 2017.69(7),pp.3943. doi:10.12816/0042589.

9. Wagner, A.L Zhang, Ying Montgomery, Jolynn $\mathrm{P}$ Ding, Yaxing Carlson, Bradley F Boulton, Matthew L'Timely measles vaccination in Tianjin ,China:a cross-sectional study of immunization records and mothers',BMC Public Health, 2014.12(888),pp.34-38. Available at:http://www. biomedcentral.com/1471-2458/14/888.

10. Weiss,C.,S,D.and Merten, S.'Parental, attitudes and practice towards measles vaccination in the canton of Aargau, Switzerland:A latent class analysis',BMC Infectious Diseases. 2016.,16(11),pp.1-8. doi:10.1186/s12879-016$1747-0$.

11. Gupta, Surender Nikhil Vidya, Ramachandran, Naveen ,Mohan DS.N.'Factors precipitating outbreaks of measles in district Kangra of North India :A case-control study', International Journal of Applied and Basic Medical Research, 2011.1(1), pp. 24-30. doi:10.4103/2229-516X.81976.

12. Abidoye,A.O.and Odeyemi,K. A.'Knowledge, Attitude and Practice of Mothers To Childhood Immunization in Kosofe Local Government Area of Lagos State, Nigeria', InternationalJournalofBasic, Applied and Innovative Research,2012,2(4),pp. 66-72.Available at:https://www.ajol .info/index. php/ijbair/ article/view/104907.

13. Farqad, A.J 'Knowledge,Attitudes and Practice of Mothers Regarding vaccination and among Sample 

5(4), pp. 22-28. doi: 10.9790/1959-0504022228. Al-Nisour Journal for Medical Sciences,2016.2, pp.288-301.

14. Ramadan, H. A., Soliman, S. M. and El-kader, R. G. A. 'Knowledge, Attitude and Practice of Mothers toward Childrens Obligatory Vaccination', Journal of Nursing and Health Science (IOSR-JNHS),2016.

15. Awring M. R. 'identifying vaccine hesitant groups in a family health center' MIDDLE EAST JOURNAL OF FAMILY MEDICINE,2018.16(6), pp. 17-26. doi: 10.5742/MEWFM.2018.93386. 